\title{
EVALUASI DAMPAK PENDIDIKAN DAN PELATIHAN PENGEMBANGAN KEPROFESIAN BERKELANJUTAN GURU MATEMATIKA DI PPPPTK MATEMATIKA YOGYAKARTA
}

\author{
Adi Wijaya ${ }^{1} *$, Sumarno $^{2}$ \\ ${ }^{1}$ PPPPTK Matematika Yogyakarta, ${ }^{2}$ Universitas Negeri Yogyakarta \\ ${ }^{1}$ Joho, Condongcatur, Kec. Depok, Kab. Sleman, Yogyakarta 55281, Indonesia \\ ${ }^{2}$ Jl. Colombo No. 1, Depok, Sleman 55281, Yogyakarta, Indonesia \\ * Corresponding Author. Email: adiwp4tkmat@gmail.com
}

\begin{abstract}
Abstrak
Penelitian ini bertujuan untuk mendeskripsikan dampak pendidikan dan pelatihan Pengembangan Keprofesian Berkelanjutan (PKB) guru matematika yang diselenggarakan di PPPPTK Matematika tahun 2013 dan 2014 terhadap perubahan perilaku alumni dalam melakukan kegiatan PKB yang meliputi: (1) bentuk kegiatan PKB setelah diklat, dan (2) kendala/hambatan dalam melakukan kegiatan PKB. Penelitian ini merupakan penelitian evaluasi dengan menggunakan model Empat Level Kirkpatrick. Sampel penelitian ini adalah alumni Diklat PKB Guru Matematika tahun 2013 dan 2014. Data dikumpulkan menggunakan kuesioner yang dikirimkan melalui pos, observasi, dan wawancara terstruktur. Data dianalisis menggunakan analisis statistik deskriptif. Hasil penelitian menunjukkan diklat PKB yang diselenggarakan PPPPTK Matematika belum berdampak banyak terhadap perubahan perilaku alumni.
\end{abstract}

Kata kunci: dampak diklat, pengembangan keprofesian berkelanjutan

\section{AN EVALUATION OF THE IMPACT OF EDUCATION AND TRAINING ON CONTINOUS PROFESSIONAL DEVELOPMENT OF MATHEMATICS TEACHERS IN PPPPTK MATHEMATICS OF YOGYAKARTA}

\begin{abstract}
This study aims to describe the impact of education and training on Continous Professional Development (CPD) of mathematics teachers held by PPPPTK Mathematics of Yogyakarta in 2013 and 2014 which includes: (1) the form of CPD activities after training, and (2) the reason for not conducting CPD. This study is evaluation research using Kirkpatrick's Four-Level Model. The sample was participants of education and training on Continous Professional Development (CPD) of mathematics teachers held by PPPPTK Mathematics of Yogyakarta in 2013 and 2014. The data were collected using questionnaires sent by mail and structured interviews, and analyzed using the descriptive analysis. The results show that education and training on Continous Professional Development (CPD) of mathematics teachers held by PPPPTK Mathematics of Yogyakarta in 2013 and 2014 do not have much impact on alumni's behavioral change.
\end{abstract}

Keywords: training impact, continous professional development

Permalink/DOI: bttp:/ / dx.doi.org/10.21831/pep.v21i2.10113

Jurnal Penelitian dan Evaluasi Pendidikan

ISSN 1410-4725 (print) ISSN 2338-6061 (online) 


\section{Pendahuluan}

Mutu pendidikan di Indonesia antara lain dapat dilihat dari hasil nilai Ujian $\mathrm{Na}-$ sional (UN), Trends in International Mathematics and Science Study (TIMSS), dan Programme for International Student Assessment (PISA). Nilai UN secara rata-rata masih jauh dari standar ketuntasan dan standar kelulusan yang sangat rendah yaitu sebesar 5,50 dari skala 10 untuk seluruh mata pelajaran yang diujikan (Badan Standar Nasional Pendidikan, 2015, p. 33). Beberapa data di atas menunjukkan bahwa kualitas mutu pendidikan di Indonesia masih belum menggembirakan.

Belum menggembirakannya mutu pendidikan di Indonesia ini tentunya juga dipengaruhi oleh kompetensi guru di Indonesai. Dari hasil uji kompetensi guru terhadap sekitar 1,6 juta guru, hasilnya belum menggembirakan karena sebagian besar nilainya di bawah 50 dari nilai tertinggi 100. Hal ini menunjukkan bahwa mutu guru Indonesia masih mengkhawatirkan (Napitupulu, 2015). Pusat Pengembangan dan Pemberdayaan Pendidik dan Tenaga Kependidikan (PPPP_ TK) Matematika merupakan salah satu Unit Pelayanan Teknis (UPT) di lingkungan Kementerian Pendidikan dan Kebudayaan yang mempunyai tugas melaksanakan pengembangan dan pemberdayaan pendidik dan tenaga kependidikan khususnya untuk bidang studi Matematika. Salah satu bentuk dari penjabaran tugas tersebut adalah melaksanakan program pendidikan dan pelatihan (diklat) bagi guru matematika di Indonesia. Salah satu permasalahan yang dihadapi PPPPTK Matematika berkaitan dengan peningkatan kompetensi (keprofesionalan) guru melalui kediklatan adalah terbatasnya kuota diklat setiap tahunnya. Oleh karena itu, untuk meningkatkan kompetensi/keprofesionalannya, guru perlu mengikuti dan melakukan berbagai bentuk kegiatan selain dalam bentuk kediklatan saja.

Guru merupakan salah satu kunci utama penentu keberhasilan proses belajar mengajar di sekolah. Oleh karena itu, guru senantiasa diharapkan selalu meningkatkan keprofesionalismenya. Peraturan Menteri Pendayagunaan Aparatur Negara dan Refor- masi Birokrasi (Permenpan dan RB) Nomor 16 Tahun 2009 tentang Jabatan Fungsional Guru dan Angka Kreditnya menyebutkan bahwa tugas guru tidak hanya mengajar, membimbing dan menilai saja, tetapi juga harus melakukan pengembangan keprofesian berkelanjutan (PKB) yang meliputi pengembangan diri, publikasi ilmiah, dan karya inovatif. Dalam peraturan tersebut disebutkan bahwa PKB adalah pengembangan kompetensi guru yang dilaksanakan sesuai dengan kebutuhan, bertahap, berkelanjutan untuk meningkatkan profesionalitasnya. (Kementerian Negara Pendayagunaan Aparatur Negara dan Reformasi Birokrasi, 2009). Sementara itu, menurut Day, PKB adalah semua pengalaman belajar yang dialami dan kegiatan-kegiatan yang secara sadar dan terencana yang dimaksudkan untuk dapat memberi manfaat, baik secara langsung maupun tidak langsung kepada individu, kelompok atau sekolah, yang berkontribusi pada kualitas pendidikan di kelas (Goodall, Day, Muijs, \& Harris, 2005, p. 6).

PKB merupakan salah satu komponen pada unsur utama yang kegiatannya diberikan angka kredit. Terdapat tiga komponen kegiatan dalam PKB yaitu pengembangan diri, publikasi ilmiah, dan karya inovatif. Kementerian Pendidikan dan Kebudayaan pada tahun 2010 secara rinci telah menguraikan jenis-jenis PKB dengan menerbitkan Buku 4 tentang Pedoman Kegiatan PKB dan Angka Kreditnya (Kementerian Pendidikan Nasional Republik Indonesia, 2010, pp. 15-60). Dalam buku tersebut diuraikan bahwa kegiatan pengembangan diri adalah kegiatan yang dilakukan guru untuk meningkatkan kompetensi dan keprofesiannya. Kegiatan tersebut dilakukan melalui pendidikan dan pelatihan (diklat) fungsional dan/ atau melalui kegiatan kolektif guru. Diklat fungsional bagi guru adalah kegiatan guru dalam mengikuti pendidikan atau latihan yang bertujuan untuk meningkatkan keprofesian guru yang bersangkutan dalam kurun waktu tertentu. Sementara itu, kegiatan kolektif guru adalah kegiatan guru dalam mengikuti kegiatan pertemuan ilmiah atau mengikuti kegiatan bersama yang dilakukan 
guru yang bertujuan untuk meningkatkan keprofesian guru yang bersangkutan. Kegiatan publikasi ilmiah dalam PKB dikelompokkan menjadi tiga kegiatan yaitu: presentasi pada forum ilmiah, publikasi hasil penelitian atau gagasan inovatif pada bidang pendidikan formal, dan publikasi buku teks pelajaran, buku pengayaan dan/atau pedoman guru. Sementara itu, komponen dimensi kegiatan karya inovatif meliputi: menemukan teknologi tepat guna; menemukan/ menciptakan karya seni; membuat/memodifikasi alat pelajaran/peraga; dan mengikuti pengembangan penyusunan standar, pedoman, soal dan sejenisnya.

Salah satu diklat yang diselenggarakan PPPPTK Matematika dalam rangka menfasilitasi guru terkait adanya Permenpan dan RB Nomor 16 Tahun 2009 dan Permendiknas Nomor 35 Tahun 2010 adalah Diklat Pengembangan Keprofesian Berkelanjutan (PKB) Guru Matematika (Pusat Pengembangan dan Pemberdayaan Pendidik dan Tenaga Kependidikan Matematika, 2013, p. 1). Diklat ini untuk pertama kalinya dilaksanakan pada tahun 2013. Diklat dikemas dalam model In On In dengan rincian: In-1 dilaksanakan selama 10 hari di PPPPTK Matematika, On (on the job learning) dilaksanakan di tempat tugas masing-masing, dan In-2 selama 3 hari di PPPPTK Matematika. Pada kegiatan $I n-1$ peserta dibekali pengetahuan dan keterampilan selama 100 jam pelajaran terkait kegiatan PKB baik unsur pengembangan diri, publikasi ilmiah, maupun karya inovatif yang kemudian diterapkan pada on the job learning di sekolah masing-masing. Pada kegiatan on the job learning, peserta diharapkan dapat melakukan dan menghasilkan suatu karya/produk PKB tertentu. Karya/produk tersebut nantinya diminta untuk ditulis dalam bentuk makalah dan dipresentasikan pada akhir kegiatan In-2. Dengan serangkaian kegiatan tersebut diharapkan guru dapat terfasilitasi, terpacu dan terdorong untuk dapat meningkatkan kompetensi dirinya sekaligus produktivitasnya dalam melakukan inovasi pembelajaran melalui berbagai kegiatan PKB.
Keberhasilan suatu program diklat dapat dilihat dari berbagai sudut pandang, tidak hanya sekedar dilihat dari tercapainya jumlah sasaran yang telah direncanakan, terselenggaranya diklat sesuai dengan waktu yang direncanakan, berjalannya semua proses diklat sesuai dengan yang sudah direncanakan, adanya peningkatan nilai pos tes terhadap nilai pre tes, maupun tercapainya kepuasan peserta terhadap penyelenggaraan diklat saja. Keberhasilan suatu program diklat juga perlu dilihat dari bagaimana perubahan perilaku peserta diklat setelah mengikuti diklat terhadap tujuan awal program diklat itu sendiri. Menurut Silberman (2006, p. 315), ketika mengetahui bagaimana pengaruh (dampak) program diklat terhadap peserta diklat berarti memiliki kesempatan untuk menilai tingkat keberhasilan program diklat yang telah dilakukan dan untuk memodifikasi apa saja yang diperlukan agar diklat lebih efektif.

Kirkpatrick Four Levels Evaluation Model merupakan model evaluasi yang sering digunakan untuk mengevaluasi program pelatihan. Model evaluasi ini terdiri atas empat tahapan evaluasi, yaitu: reaction, learning, behavior, dan result. Evaluasi program diklat yang selama ini dilakukan oleh PPPPTK Matematika masih sebatas untuk mengetahui: (1) penilaian peserta diklat terhadap penyelenggaraan diklat; (2) penilaian peserta terhadap penyaji (fasilitator) diklat; (3) tingkat kelulusan peserta; dan (4) kenaikan rata-rata nilai tes awal terhadap tes akhir. Jika dilihat dari tahapan model evaluasi yang dikembangkan oleh Kirkpatrick, evaluasi diklat yang diselenggarakan PPPPTK Matematika tersebut baru dilakukan pada tahap reaction dan learning saja.

PPPPTK Matematika menyelenggarakan Diklat Pengembangan Keprofesian Berkelanjutan (PKB) untuk pertama kalinya pada tahun 2013. Diklat ini dilaksanakan dalam rangka mendukung keterlaksanaan Permenpan dan RB nomor 16 tahun 2009 dan Permendiknas nomor 35 tahun 2010 khususnya dalam melakukan kegiatan PKB. Evaluasi diklat yang dilakukan selama ini baru sebatas untuk mengetahui tingkat ke- 
puasan peserta terhadap proses penyelenggaraan diklat dan peningkatan pengetahuan peserta setelah mengikuti diklat (tahap 1 dan 2) saja. Evaluasi diklat yang dilakukan belum sampai untuk mengetahui bagaimana dampak diklat setelah selesai mengikuti diklat, yaitu pada tahap 3 dan 4 .

Dalam penelitian ini, dampak diklat yang diteliti dibatasi pada dampak diklat tahap 3, khususnya bagi diri alumni sendiri, yaitu dampak diklat terhadap perubahan perilaku alumni dalam melakukan kegiatan PKB setelah selesai mengikuti diklat serta faktor-faktor apa saja yang menjadi kendalanya. Oleh karena itu, masalah yang akan dikaji dalam penelitian ini adalah: "Bagaimanakah deskripsi dampak diklat PKB guru Matematika yang diselenggarakan PPPPTK Matematika tahun 2013 dan 2014? Secara operasional masalah tersebut diuraikan menjadi: (1) Apa sajakah bentuk kegiatan PKB pada dimensi pengembangan diri, publikasi ilmiah, dan karya inovatif yang dilakukan alumni setelah selesai mengikuti diklat PKB yang diselenggarakan PPPPTK Matematika? dan (2) Apa sajakah faktor-faktor yang sering menjadi alasan bagi alumni yang belum melakukan kegiatan PKB?

Hasil penelitian ini diharapkan berguna untuk: (1) bahan masukan bagi lembaga kediklatan, khususnya PPPPTK Matemati$\mathrm{ka}$, dalam memperbaiki maupun mengembangkan program diklat PKB baik dari segi struktur program diklatnya maupun model diklatnya; dan (2) bahan pertimbangan bagi para stakeholder dalam menyempurnakan atau merancang program kegiatan yang bertujuan untuk memfasilitasi guru dalam melakukan PKB sesuai Permenpan dan RB nomor 16 tahun 2009 dan Permendiknas nomor 35 tahun 2010.

\section{Metode Penelitian}

Penelitian ini merupakan penelitian evaluasi dengan pendekatan deskriptif. Tujuan penelitian ini lebih difokuskan untuk mendeskripsikan bagaimana dampak dari suatu program diklat terhadap perubahan perilaku guru alumni setelah selesai mengikuti diklat. Penelitian ini terlebih dahulu diawali dengan mendeskripsikan bagaimana pelaksanaan penyelenggaraan program diklat tersebut yang telah dilakukan oleh PPPPTK Matematika. Oleh karena itu, model evaluasi yang digunakan dalam penelitian ini adalah model evaluasi empat level dari Kirkpatrick. Penelitian yang dilakukan difokuskan untuk mengevaluasi kegiatan pasca diklat. Evaluasi pasca diklat lebih difokuskan lagi untuk mendeskripsikan perubahan perilaku guru alumni dalam melakukan kegiatan PKB setelah selesai mengikuti diklat (level behavior) menurut Permenpan dan RB nomor 16 tahun 2009 dan Permendiknas nomor 35 tahun 2010 serta faktor-faktor yang menjadi penyebab belum dilakukannya.

Populasi penelitian ini adalah seluruh alumni Diklat PKB Guru Matematika yang diselenggarakan di PPPPTK Matematika tahun 2013 dan 2014 yang berjumlah 78 orang. Mengingat populasi yang kecil maka hampir seluruh populasi (68 orang) digunakan sebagai sampel. Alasan yang lain, yakni 10 orang tidak dijadikan sebagai sampel dikarenakan 8 orang tidak dapat menyelesaikan diklat secara tuntas, 1 orang sudah menjadi kepala sekolah dan 1 orang sakit yang kurang memungkinkan untuk diteliti.

Teknik pengumpulan data dalam penelitian ini menggunakan kuesioner, wawancara, dan studi dokumentasi. Pengembangan instrumen penelitian yang digunakan didasarkan pada kajian teori yang telah dilakukan sebelumnya. Atas dasar kajian teori kemudian ditentukan dimensi serta indikator penelitian yang selanjutnya dituangkan dalam kisi-kisi instrumen dan kemudian dijabarkan dalam sejumlah butir pernyataan/ pertanyaan. Instrumen yang digunakan untuk mengumpulkan data dampak diklat PKB memuat tiga dimensi kegiatan PKB yaitu pengembangan diri, publikasi ilmiah, dan karya inovatif. Komponen pada dimensi kegiatan pengembangan diri meliputi kegiatan diklat fungsional dan kegiatan kolektif guru. Semantara itu, komponen pada dimensi kegiatan publikasi ilmiah meliputi kegiatan presentasi pada forum ilmiah, publikasi ilmiah atas hasil penelitian atau gagasan inovatif pada bidang pendidikan formal, 
dan publikasi buku teks pelajaran, buku pengayaan, dan pedoman guru. Selanjutnya, komponen pada dimensi kegiatan karya inovatif meliputi: menemukan teknologi tepat guna; menemukan/menciptakan karya seni; membuat/memodifikasi alat pelajaran/peraga; dan mengikuti pengembangan penyusunan standar, pedoman, soal dan sejenisnya.

Validitas isi diperoleh dari hasil penilaian para pakar terhadap instrumen penelitian yang telah disusun dengan menggunakan rumus Aiken. Sementara itu, validitas konstruk dilakukan menggunakan bantuan program SmartPLS 3 versi Student. Program SmartPLS 3 versi Student digunakan untuk mengevaluasi pengukuran model yang digunakan. Menurut Abdillah \& Jogiyanto (2015, p. 164) Partial Least Square (PLS) adalah analisis persamaan struktural (SEM) berbasis varian yang secara simultan dapat melakukan pengujian model pengukuran sekaligus pengujian model struktural. Beberapa kelebihan penggunaan PLS di antaranya yaitu data tidak harus berdistribusi normal, dapat menggunakan ukuran sampel yang kecil, dan tidak mengharuskannya randomisasi sampel (Sarwono \& Narimawati, 2015, p. 12). Dalam PLS, validitas konstruk terdiri atas validitas konvergen dan validitas diskriminan. Menurut Hair, Hult, Ringle, \& Sarstedt (2014, p. 107) aturan yang digunakan untuk mengevaluasi pengukuran model reflektif pada validitas konvergen adalah nilai AVE lebih besar dari 0,50. Sementara itu, untuk validitas diskriminan adalah nilai loading dari masingmasing indikator terhadap konstruknya lebih besar daripada semua nilai cross loading konstruk lainnya. Selanjutnya, uji reliabilitas dalam PLS dapat menggunakan dua metode, yaitu Cronbach's alpha dan Composite reliability. Untuk dapat dikatakan suatu konstruk yang reliabel, maka nilai Cronbach's alpha harus $>0,6$ dan Composite reliability harus $>$ 0,7 (Abdillah \& Jogiyanto, 2015, p. 207).

Analisis data dalam penelitian ini menggunakan bantuan program SmartPLS 3 versi Student dan progrsm Ms Excel 2010. Program SmartPLS 3 versi Student digunakan untuk mengevaluasi pengukuran model yaitu untuk melihat validitas dan reliabilitas instrumen yang digunakan. Mengingat penelitian ini adalah penelitian evaluasi deskriptif maka analisis data yang juga digunakan adalah analisis data secara deskriptif analitik dengan menggunakan analisis statistik deskriptif. Statistik deskriptif yang digunakan adalah persentase.

\section{Hasil Penelitian dan Pembahasan}

Validitas isi dilakukan terhadap kisi-kisi instrumen, kuesioner, pedoman wawancara, dan panduan dokumentasi. Validitas isi dilakukan oleh 6 orang ahli dibidang pengukuran (1 orang), evaluasi ( 2 orang), metodologi (1 orang), pendidikan matematika (1 orang) dan kediklatan (1 orang). Hasil penilaian para ahli terhadap kisi-kisi instrumen, kuesioner, panduan wawancara, dan pedoman studi dokumentasi yang dipergunakan untuk mengungkap dampak diklat PKB terhadap dimensi pengembangan diri, publikasi ilmiah, dan karya inovatif alumni diklat semuanya mempunyai nilai Aiken diatas 0,7. Hasil ini menunjukkan bahwa instrumen penelitian yang digunakan mempunyai validitas isi yang baik dikarenakan semua nilai Aiken diatas 0,7 (Azwar, 2012, p. 113). Sementara itu, uji keterbacaan instrumen dilakukan oleh 6 orang alumni diklat yang mewakili alumni dari jenjang SD (1 orang), SMP (2 orang), SMA (2 orang), dan SMK (1 orang). Rata-rata hasil uji keterbacaan terhadap instrumen kuesioner yang digunakan adalah 4,72 dengan rentang skor yang digunakan dalam menilai keterbacaan instrumen kuesioner adalah 1 (sangat kurang) sampai dengan 5 (amat baik). Nilai rata-rata uji keterbacaan kuesioner sebesar 4,72 menunjukkan bahwa instrumen kuesioner yang dipergunakan untuk menjaring informasi dampak diklat PKB dalam kategori "Amat Baik" dari segi keterbacaan sehingga dapat dipergunakan.

Evaluasi model pengukuran dilakukan dengan menggunakan bantuan software SmartPLS 3 Student version. Hasil keluaran model pengukuran menyajikan bukti validitas konstruk, yaitu validitas konvergen dan 
validitas diskriminan serta bukti reliabilitas. Bukti validitas konstruk model dapat dilihat pada Tabel 1 dan Tabel 2.

Tabel 1. Bukti Validitas Konvergen

\begin{tabular}{cc}
\hline Dimensi & AVE \\
\hline Pengembangan Diri & 0,504 \\
Publikasi Ilmiah & 0,529 \\
Karya Inovatif & 0,571 \\
\hline
\end{tabular}

Tabel 2. Bukti Validitas Diskriminan (Cross loadings)

\begin{tabular}{lccc}
\hline & $\begin{array}{c}\text { Pengemb } \\
\text { Diri }\end{array}$ & $\begin{array}{c}\text { Publikasi } \\
\text { Ilmiah }\end{array}$ & $\begin{array}{c}\text { Karya } \\
\text { Inovatif }\end{array}$ \\
\hline DF.2 & 0,624 & 0,178 & 0,074 \\
KKG.1 & 0,653 & 0,271 & 0,134 \\
KKG.4 & 0,834 & 0,429 & 0,447 \\
PFI.1 & 0,459 & 0,661 & 0,354 \\
PFI.2 & 0,181 & 0,755 & 0,017 \\
PHGI & 0,344 & 0,845 & 0,180 \\
PHP & 0,245 & 0,720 & 0,024 \\
PBTP & 0,319 & 0,638 & 0,061 \\
KIAP & 0,217 & 0,110 & 0,812 \\
KIAPRG & 0,292 & 0,164 & 0,803 \\
KIPS & 0,313 & 0,123 & 0,641 \\
\hline
\end{tabular}

Tabel 1 menunjukkan bahwa nilai AVE pada semua dimensi PKB lebih besar dari 0,50. Hal ini menunjukkan bahwa tidak terdapat permasalahan pada validitas konvergen. Selanjutnya, pada Tabel 2, bukti validitas diskriminan, menunjukkan bahwa nilai loading dari masing-masing indikator terhadap konstruknya lebih besar daripada nilai cross loading nya. Berdasar hasil analisa cross loading tersebut tampak bahwa sudah tidak terdapat permasalahan dalam validitas diskriminan.

Estimasi reliabilitas dalam PLS menggunakan dua metode, yaitu Cronbach's alpha dan Composite reliability. Dalam penelitian ini, reliabilitas menggunakan ketentuan jika nilai Composite reliability $>0,7$. Bukti reliabilitas instrumen dapat dilihat pada Tabel 3.

Tabel 3. Bukti Reliabilitas

\begin{tabular}{lc}
\hline Dimensi PKB & Composite reliability \\
\hline Pengembangan Diri & $0,750(0,8)$ \\
Publikasi Ilmiah & $0,848(0,8)$ \\
Karya Inovatif & $0,798(0,8)$ \\
\hline
\end{tabular}

Pada Tabel 3 terlihat bahwa ketiga dimensi instrumen PKB mempunyai nilai Composite reliability lebih dari 0,7 sehingga dapat dikatakan bahwa syarat reliabilitas ketiga dimensi PKB tersebut sudah terpenuhi.

Penelitian ini lebih difokuskan untuk mengetahui dampak dari pelaksanaan program Diklat Pengembangan Keprofesian Berkelanjutan (PKB) Guru Matematika yang diselenggarakan oleh P4TK Matematika tahun 2013 dan 2014 terhadap perubahan perilaku alumni dalam melakukan kegiatan PKB setelah selesai mengikuti diklat. Dengan kata lain, penelitian ini mengevaluasi tahap 3 (bevaior) pada model evaluasi Kirckpatrik. Evaluasi pada tahap behavior berarti melakukan pengukuran terhadap perilaku peserta di lingkungan kerjanya sebagai akibat dari program diklat yang diikutinya. Menurut Kirkpatrick \& Kirkpatrick (2006, p. 52), pada level behavior ini berusaha untuk mengevaluasi seberapa banyak "transfer of knowledge, skills, and attitudes" terjadi sebagai akibat dari program diklat yang diikutinya. Ini berarti pada tahap ini ingin mengetahui perubahan perilaku apa saja yang terjadi dalam melaksanakan tugas pekerjaanya sebagai akibat dari program diklat yang telah diikutinya. Perubahan perilaku yang diteliti adalah perubahan perilaku guru alumni terhadap kegiatan PKB sesuai dengan Permenegpan dan RB nomor 16 Tahun 2009 dan Permendiknas nomor 35 tahun 2010. Dengan kata lain, pada tahap behavior ini ingin diketahui: (a) apa sajakah bentuk kegiatan PKB pada dimensi pengembangan diri, publikasi ilmiah, dan karya inovatif yang dilakukan alumni setelah selesai mengikuti dikla? (b) apa sajakah faktor-faktor yang menjadi alasan bagi alumni yang belum melakukan kegiatan PKB pada dimensi pengembangan diri, publikasi ilmiah, dan karya inovatif?

Bentuk Kegiatan PKB Alumni setelah Selesai Mengikuti Diklat

Deskripsi bentuk kegiatan PKB yang dilakukan alumni setelah selesai mengikuti diklat dalam penelitian ini difokuskan pada kegiatan PKB menurut Permenpan dan RB Nomor 16 Tahun 2009 dan Permendiknas nomor 35 tahun 2010 yang dikelompokkan 
menjadi tiga dimensi kegiatan yaitu pengembangan diri, publikasi ilmiah, dan karya inovatif. Deskripsi bentuk kegiatan PKB ini didasarkan pada hasil pengolah data dari 61 kuesioner yang kembali ke peneliti (90\%).

\section{Dimensi Pengembangan Diri}

Kegiatan pengembangan diri adalah kegiatan yang dilakukan guru untuk meningkatkan kompetensi dan keprofesiannya. Kegiatan tersebut dilakukan melalui pendidikan dan pelatihan (diklat) fungsional dan/ atau melalui kegiatan kolektif guru. Diklat fungsional terdiri atas dua indiktor, yaitu mengikuti diklat/kursus atas inisiatif sendiri dan mengikuti diklat/kursus atas usulan sekolah/dinas pendidikan.

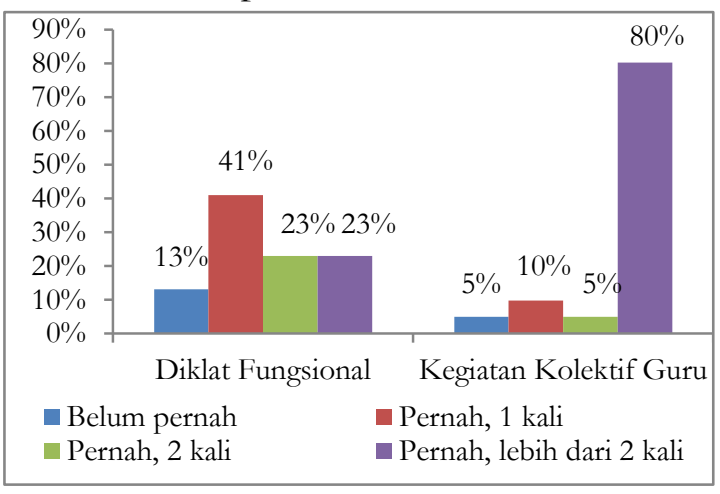

Gambar 1. Kegiatan PKB pada

Dimensi Pengembangan Diri

Gambar 1 menunjukkan bahwa terdapat $87 \%$ alumni yang sudah pernah mengikuti diklat fungsional setelah selesai mengikuti diklat PKB. Sebanyak 31\% alumni mengikuti diklat/kursus atas inisiatif sendiri dan $77 \%$ alumni mengikuti diklat/kursus atas usulan sekolah/dinas pendidikan. Diklat/kursus atas inisiatif sendiri yang diikuti tersebut terkait dengan materi: kurikulum 2013; penilaian kinerja guru; karya tulis ilmiah; matematika praktis; pembelajaran matematika; media pembelajaran; dan perpustakaan. Sementara itu, diklat/kursus atas usulan sekolah/dinas pendidikan yang diikuti tersebut terkait dengan materi: Kuriulum 2013; penilaian kinerja guru; media; penulisan soal; KTI; Bahasa Inggris; pedagogi; dan pembelajaran matematika.

Kegiatan kolektif guru adalah kegiatan guru dalam mengikuti kegiatan pertemu- an ilmiah atau mengikuti kegiatan bersama yang dilakukan guru yang bertujuan untuk meningkatkan keprofesian guru yang bersangkutan (Kementerian Pendidikan Nasional Republik Indonesia, 2010, p. 17). Kegiatan kolektif guru terdiri atas empat indikator, yaitu mengikuti kegiatan lokakarya atau IHT, mengikuti kegiatan pertemuan rutin di KKG/MGMP, menjadi pembahas dalam kegiatan seminar/kolokium/diskusi panel/ lainnya, dan menjadi peserta dalam kegiatan seminar/kolokium/diskusi panel/lainnya. Pada Gambar 1 menunjukkan bahwa terdapat 95\% alumni yang sudah pernah mengikuti kegiatan kolektif guru setelah 8 selesai mengikuti diklat PKB. Sebanyak 58\% alumni mengikuti kegiatan lokakarya atau IHT, $84 \%$ alumni mengikuti kegiatan pertemuan rutin di KKG/MGMP, 25\% menjadi pembahas dalam seminar/kolokium/diskusi panel, dan 57\% menjadi peserta dalam kegiatan seminar/kolokium/diskusi panel. Kegiatan lokakarya atau IHT yang diikuti tersebut berkaitan dengan penyusunan perangkat kurikulum, pembelajaran berbasis TIK, penilaian, pengembangan media pembelajaran, dan/atau kegiatan lainnya terkait dengan materi: Kurikulum 2013; pembuatan kisi-kisi soal UN; OSN; penyusunan program sekolah; PTK; dan media pembelajaran seperti: Etmudo, Lectora, Maple, Geogebra, Macromedia flash, dan e-learning.

Berdasarkan besarnya persentase alumni yang melakukan kegiatan pada dimensi pengembangan diri, baik itu mengikuti kegiatan diklat fungsional maupun kegitan kolektif guru dan melihat mata diklat yang diberikan, khususnya terkait dengan pengembangan diri maka dapat dikatakan bahwa diklat PKB yang dilakukan sudah memberikan dampak yang sangat banyak terhadap perubahan perilaku guru dalam mengikuti kegiatan diklat fungsional maupun kegiatan kolektif guru.

\section{Dimensi Publikasi Ilmiah}

Buku 4 pedoman kegiatan PKB menyatakan bahwa kegiatan publikasi ilmiah dikelompokkan menjadi tiga kegiatan yaitu: presentasi pada forum ilmiah; publikasi hasil penelitian atau gagasan inovatif pada bidang 
pendidikan formal, dan publikasi buku teks pelajaran, buku pengayaan dan/atau pedoman guru. Presentasi pada forum ilmiah terdiri atas 2 indiktor, yaitu menjadi pemrasaran/pemakalah pada kegiatan seminar/lokakarya ilmiah dan menjadi pemrasaran/pemakalah pada kegiatan kolokium atau diskusi ilmiah.

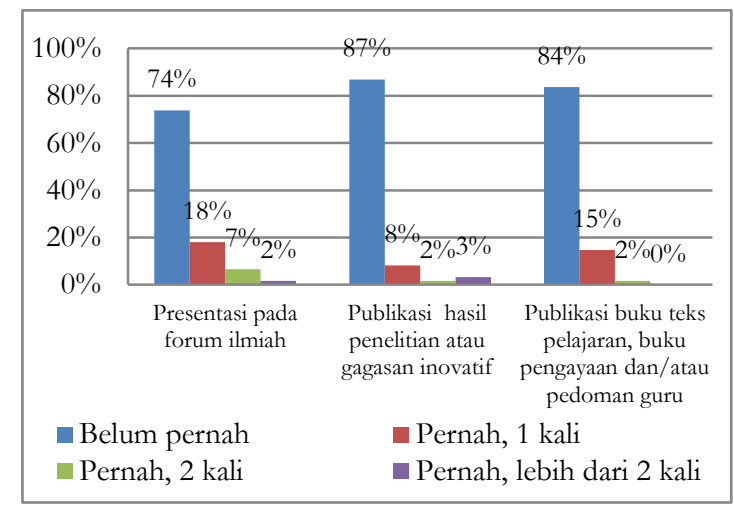

Gambar 2. Kegiatan PKB Alumni pada Dimensi Publikasi Ilmiah

Gambar 2 menunjukkan bahwa terdapat $26 \%$ alumni yang sudah pernah melakukan kegiatan presentasi pada forum ilmiah. Presentasi pada forum ilmiah yang pernah diikuti tersebut, sebanyak $26 \%$ alumni pernah menjadi pemrasaran/pemakalah pada kegiatan seminar/lokakarya ilmiah dan $2 \%$ alumni pernah menjadi pemrasaran/pemakalah pada kegiatan kolokium atau diskusi ilmiah.

Kegiatan publikasi hasil penelitian atau gagasan inovatif terdiri atas dua indiktor, yaitu publikasi ilmiah dalam bentuk karya tulis ilmiah berupa laporan hasil penelitian dan publikasi ilmiah dalam bentuk makalah tinjauan ilmiah, tulisan ilmiah populer, dan artikel ilmiah populer. Terdapat 13\% alumni yang pernah melakukan ke-giatan publikasi hasil penelitian atau gagasan inovatif. Sebanyak $7 \%$ dalam bentuk karya tulis ilmiah berupa laporan hasil penelitian dan 11\% alumni dalam bentuk makalah tinjauan ilmiah, tulisan ilmiah populer, dan artikel ilmiah populer. Jika dilihat dari materi diklat yang pernah diterima dan kecilnya persentase alumni yang pernah melakukan kegiatan publikasi hasil penelitian atau gagasan inovatif, maka hasil penelitian ini menunjukkan bahwa dik- lat PKB yang pernah diikutinya baru memberikan dampak yang sangat kecil terhadap alumni dalam melakukan kegiatan publikasi hasil penelitian atau gagasan inovatif.

Selanjutnya, terkait publikasi buku teks pelajaran, buku pengayaan dan/atau pedoman guru, terdapat $16 \%$ alumni yang pernah melakukannya dalam bentuk modul/ diktat pembelajaran yang digunakan di tingkat kabupaten/sekolah. Jika dilihat dari materi diklat yang pernah diterima dan kecilnya persentase alumni yang pernah melakukannya, maka hasil penelitian ini menunjukkan bahwa diklat PKB yang pernah diikutinya belum memberikan dampak yang besar dalam melakukan kegiatan publikasi ilmiah dalam bentuk publikasi buku teks pelajaran, buku pengayaan dan/atau pedoman guru.

Berdasarkan kecilnya persentase alumni yang melakukan kegiatan PKB pada dimensi publikasi ilmiah, baik itu mengikuti kegiatan presentasi pada forum ilmiah, publikasi hasil penelitian atau gagasan inovatif, maupun publikasi buku teks pelajaran, buku pengayaan atau pedoman guru dan melihat beberapa mata diklat yang diberikan, khususnya terkait dengan publikasi ilmiah maka dapat dikatakan bahwa diklat PKB yang pernah diikutinya belum memberikan dampak yang besar terhadap perubahan perilaku guru dalam melakukan kegiatan publikasi ilmiah. Ini artinya beberapa mata diklat tersebut perlu dicermati kembali apakah sudah cukup untuk memberikan bekal dalam melakukan kegiatan publikasi ilmiah.

\section{Dimensi Karya Inovatif}

Kegiatan PKB pada dimensi karya inovatif terdiri atas empat kegiatan, yaitu: menemukan teknologi tepat guna (karya sains/teknologi); menemukan/menciptakan karya seni; membuat/memodifikasi alat pelajaran/peraga; dan mengikuti pengembangan penyusunan standar, pedoman, soal dan sejenisnya.

Gambar 3 menunjukkan bahwa terdapat $21 \%$ alumni yang pernah melakukan kegiatan penemuan teknologi tepat guna (karya sains). Jika dilihat dari materi diklat yang pernah diterima dan kecilnya persen- 
tase alumni yang pernah melakukan setelah 8 bulan selesai mengikuti diklat, maka hasil penelitian ini menunjukkan bahwa diklat PKB yang pernah diikutinya belum memberikan dampak yang banyak terhadap alumni dalam melakukan kegiatan penemuan teknologi tepat guna (karya sains) dalam bentuk media pembelajaran/bahan ajar interaktif berbasis komputer, program aplikasi komputer, dan hasil pengembangan metodologi/evaluasi pembelajaran.

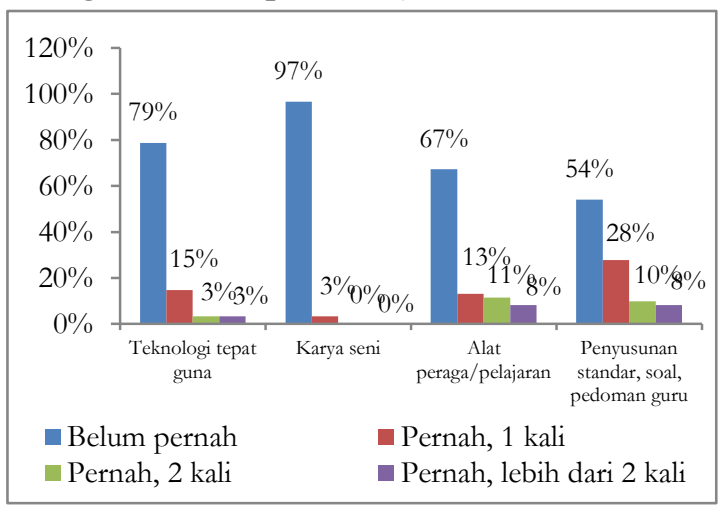

Gambar 3. Kegiatan PKB Alumni pada Dimensi Karya Inovatif

Selanjutnya, terkait dengan penemuan/penciptaan karya seni, hanya terdapat 3\% alumni yang pernah melakukan kegiatan tersebut. Hasil penelitian ini menunjukkan bahwa diklat PKB yang pernah diikutinya belum memberikan dampak yang banyak terhadap alumni dalam melakukan kegiatan penemuan/penciptaan karya seni. Ini bisa dimungkinkan karena tidak adanya materi diklat yang secara khusus terkait dengan penemuan/penciptaan karya seni bagi guru matematika. Sementara itu, terkait dengan kegiatan pembuatan/pemodifikasian alat peraga/alat pelajaran, terdapat 33\% alumni yang pernah melakukannya. Sebanyak $18 \%$ alumni pernah melakukan kegiatan membuat/ memodifikasi alat pelajaran dan $28 \%$ alumni yang sudah pernah melakukan kegiatan membuat/memodifikasi alat peraga. Jika dilihat dari materi diklat yang pernah diterima dan kecilnya persentase alumni yang pernah melakukan setelah 8 bulan selesai mengikuti diklat, maka hasil penelitian ini menunjukkan bahwa diklat PKB yang pernah diikutinya belum memberikan dam- pak yang besar terhadap alumni dalam melakukan kegiatan pembuatan/pemodifikasian alat peraga/alat pelajaran.

Kegiatan pengembangan penyusunan standar, pedoman, soal, dan sejenisnya yang pernah dilakukan alumni terdapat sebanyak $46 \%$ yang pernah melakukannya. Kegiatan tersebut, sebanyak $44 \%$ pernah melakukan pengembangan penyusunan soal tingkat nasional/provinsi/ kabupaten dan sebanyak $10 \%$ alumni yang pernah melakukan kegiatan pengembangan penyusunan standar atau pedoman dan sejenisnya. Ini artinya bahwa terdapat 54\% alumni belum pernah melakukannya. Jika dilihat dari materi diklat yang pernah diberikan, yaitu pengembangan bank soal dan pengembangan instrumen tes maka hasil penelitian ini menunjukkan bahwa diklat PKB yang pernah diikutinya belum memberikan dampak yang besar terhadap alumni dalam melakukan kegiatan pengembangan penyusunan standar, pedoman, soal, dan sejenisnya, khususnya keterlibatan dalam penyusunan soal baik tingkat nasional, provinsi, maupun kabupaten.

Berdasarkan kecilnya persentase alumni yang melakukan kegiatan PKB pada dimensi karya inovatif dan melihat beberapa mata diklat yang diberikan, khususnya terkait dengan karya inovatif maka dapat dikatakan bahwa diklat PKB yang pernah diikutinya belum memberikan dampak yang besar terhadap perubahan perilaku guru dalam melakukan kegiatan karya inovatif. Ini artinya beberapa mata diklat yang diberikan perlu dicermati kembali apakah sudah cukup untuk memberikan bekal dalam melakukan kegiatan karya inovatif.

Berdasarkan deskripsi bentuk-bentuk kegiatan $\mathrm{PKB}$ pada dimensi pengembangan diri, publikasi ilmiah, dan karya inovatif yang diuraikan di atas, terlihat bahwa Diklat PKB Guru Matematika yang diselenggarakan di PPPPTK Matematika tahun 2013 dan 2014 belum berdampak banyak terhadap perubahan perilaku alumni dalam melakukan kegiatan PKB menurut Permenpan dan RB Nomor 16 Tahun 2009 dan Permendiknas Nomor 35 tahun 2010 serta bentuknya masih bervariasi. Alumni yang sangat banyak 
melakukan kegiatan PKB baru terjadi pada dimensi pengembangan diri yaitu dengan mengikuti kegiatan diklat fungsional dan mengikuti kegiatan kolektif guru. Inipun lebih dikarenakan adanya kegiatan sosialisasi kurikulum baru (Kurikulum 2013) yang dilakukan serentak secara nasional. Sementara itu, pada dimensi publikasi ilmiah dan karya inovatif, baru sedikit dan sangat sedikit alumni yang melakukannya. Bentuk kegiatan PKB pada publikasi ilmiah tersebut yaitu: presentasi pada forum ilmiah, publikasi ilmiah hasil penelitian atau gagasan inovatif, dan publikasi buku teks pelajaran, buku pengayaan dan/atau pedoman guru. Bentuk kegiatan PKB pada dimensi karya inovatif yaitu: menemukan teknologi tepat guna (karya sains), menemukan/menciptakan karya seni, membuat/memodifikasi alat pelajaran/peraga, dan mengikuti penyusunan standar, pedoman, soal dan sejenisnya.

Terdapat beberapa faktor yang mempengaruhi belum banyaknya perubahan perilaku alumni dalam melakukan kegiatan PKB setelah mengikuti diklat. Selain faktor ketepatan atau kesesuaian mata diklat yang diberikan, salah satu faktor yang dapat menjadi penyebab masih sedikitnya perubahan yang terjadi adalah dimungkinkan belum berfungsinya secara maksimal peran dari masing-masing unsur yang terlibat dalam proses pelatihan. Tindak lanjut peserta diklat setelah kembali dari diklat dimungkinkan belum selalu direncanakan/dilaksanakan dengan baik oleh institusi terkait (sekolah/ dinas pendidikan/PPPPTK Matematika). Menurut Lynton \& Pareek (1978, p. 27), ada tidaknya dukungan organisasi akan berpengaruh terhadap dorongan untuk bersikap lebih efektif dalam usahanya menggunakan apa yang telah dipelajari selama diklat. Ini artinya bahwa setelah selesai diklat, peserta masih tetap membutuhkan dukungan dari sekolah, dinas pendidikan, maupun lembaga diklat untuk dapat menerapkan apa yang telah diperoleh selama mengikuti diklat.

Faktor-Faktor yang Menjadi Kendala/ Hambatan dalam Melakukan Kegiatan PKB

Deskripsi faktor-faktor yang menjadi alasan alumni belum melakukan kegiatan
PKB setelah selesai mengikuti diklat dalam penelitian ini difokuskan pada kegiatan PKB menurut Permenpan dan RB nomor 16 Tahun 2009 dan Permendiknas nomor 35 tahun 2010 yang dikelompokkan menjadi tiga dimensi kegiatan yaitu pengembangan diri, publikasi ilmiah, dan karya inovatif. Deskripsi ini didasarkan pada hasil wawancara terhadap 34 alumni diklat PKB tahun 2013 dan jawaban tertulis dari 27 alumni diklat PKB tahun 2014.

\section{Dimensi Pengembangan Diri}

Dimensi pengembangan diri alumni terdiri atas diklat fungsional dan kegiatan kolektif guru. Beberapa alasan yang dikemukakan mengapa belum mengikuti kegiatan diklat fungsional adalah: keterbatasan waktu baik itu karena adanya tugas tambahan sebagai wakil kepala sekolah, bendahara, maupun banyaknya beban jam mengajar; merasa tidak enak untuk ijin meninggalkan jam mengajar; belum mengetahui caranya atau prosedurnya untuk mengikuti diklat secara mandiri; tidak mengetahui ada tidaknya informasi terkait diklat secara mandiri; belum merasa membutuhkan; belum termotivasi; diklat yang tersedia tidak sesuai dengan keinginan; merasa belum ada tuntutan; belum ada tawaran untuk mengikuti; belum pernah tahu adanya informasi mengenahi kegiatan kolokium/diskusi panel; belum pernah tahu seperti apa kegiatan kolokium/diskusi panel; keterbatasan fasilitas internet untuk mengikuti diklat mandiri secara online. Sementara itu, beberapa alasan yang dikemukakan mengapa belum mengikuti kegiatan kolektif guru adalah: belum pernah ada tawaran untuk mengikuti kegiatan lokakarya/ IHT, keterbatasan dana sehingga hanya perwakilan saja yang mengikuti, keterbatasan waktu, merasa belum ada tuntutan, KKG/ MGMP tidak aktif, belum pernah ada yang menawari untuk menjadi pembahas dan jika ada yang menawaripun belum tentu bersedia karena merasa tidak mampu, belum termotivasi karena sudah tercukupi dari segi angka kredit/sertifikasi, tema kurang menarik/tidak sesuai, merasa tidak enak karena sudah sering meninggalkan sekolah, masih merasa belum menjadi tuntutan, belum per- 
nah tahu adanya informasi mengenahi kegiatan kolokium/diskusi panel dan belum pernah tahu seperti apa kegiatan kolokium/ diskusi panel.

Berdasarkan beberapa alasan yang dikemukakan tersebut di atas, yang sering disampaikan mengapa belum melakukan kegiatan PKB pada sub dimensi diklat fungsional adalah dikarenakan tidak adanya tawaran untuk mengikuti kegiatan diklat/ kursus, belum tahu caranya/prosedurnya, dan keterbatasan waktu karena beban mengajar maupun adanya tugas tambahan lain. Sementara itu, untuk kegiatan kolektif guru, alasan yang paling sering dikemukakan adalah tidak adanya tawaran untuk mengikuti kegiatan kolektif guru, keterbatasan waktu, belum pernah ada informasi adanya kegiatan seperti kolokium maupun diskusi panel, dan bahkan belum mengetahui seperti apa kegiatan kolokium maupun diskusi panel.

Terdapat beberapa pertimbangan atau saran yang diusulkan agar setelah selesai mengikuti diklat PKB alumni dapat terfasilitasi secara lebih optimal dalam melakukan kegiatan PKB pada dimensi pengembangan diri. Pertama, terkait dengan struktur program diklat $\mathrm{PKB}$, perlu ada materi diklat yang secara khusus membahas bagaimana cara meningkatkan profesionalisme guru secara berkelanjutan melalui diklat fungsional, khususnya bagaimana cara mengikuti diklat/kursus secara mandiri dengan diberikan contoh-contoh konkritnya. Hal ini diperlukan mengingat sebagian besar guru berpandangan bahwa dapat mengikuti diklat kalau ada tawaran atau undangan diklat. Kedua, perlu ada yang memfasilitasi adanya kegiatan kolokium maupun diskusi panel yang melibatkan guru. Hal ini mengingat hampir semua alumni menyatakan belum pernah mengetahui adanya kegiatan seperti kolokium maupun diskusi panel.

Dimensi Publikasi Ilmiah

Dimensi publikasi ilmiah terdiri atas presentasi pada forum ilmiah, publikasi hasil penelitian atau gagasan inovatif, dan publikasi buku teks pelajaran, buku pengayaan dan/atau pedoman guru. Beberapa alasan yang dikemukakan mengapa belum meng- ikuti kegiatan presentasi pada forum ilmiah adalah: masih belum percaya diri; belum ada tawaran untuk menjadi pemrasaran/pemakalah pada kegiatan seminar/lokakarya ilmiah/kolokium/diskusi panel; tidak mempunyai bahan untuk diseminarkan; belum termotivasi/tertarik menjadi pemakalah; belum terpikirkan menjadi pemakalah karena kesibukan tugas sekolah; belum tahu/paham terkait kegiatan kolokium/diskusi panel. Sementara itu, beberapa alasan yang dikemukakan mengapa belum melakukan kegiatan publikasi hasil penelitian atau gagasan inovatif adalah: merasa masih belum mampu/ percaya diri; keterbatasan waktu karena beban tugas kerja; belum termotivasi; belum mempunyai bahan untuk ditulis; belum merupakan tuntutan (keharusan).

Selanjutnya beberapa alasan yang dikemukakan mengapa belum melakukan kegiatan publikasi buku teks pelajaran, buku pengayaan dan/atau pedoman guru adalah: belum ada minat dikarenakan: sudah ada buku penunjang, belum jelas tuntutannya, dan angka kredit yang dibutuhkan sudah terpenuhi dengan yang lain; merasa belum ada tuntutan; keterbatasan waktu; belum ada motivasi karena merasa sulit lolos (tidak mungkin lolos karena tidak punya kenalan); merasa belum ada tuntutan dan membutuhkan waktu lama tetapi nilai angka kredit kecil; merasa sudah ada buku yang disediakan pemerintah; belum percaya diri untuk menyusun buku; belum mempunyai ide/bahan; merasa kemampuan IT kurang; belum mengetahui kurikulum 2013 sehingga belum tahu materinya; dan tidak tahu kalau masih bisa membuat buku meskipun sudah disediakan pemerintah.

Berdasarkan beberapa alasan yang dikemukakan tersebut di atas, yang sering disampaikan mengapa belum melakukan kegiatan PKB pada kegiatan presentasi pada forum ilmiah adalah dikarenakan tidak adanya tawaran untuk menjadi pemrasaran/ pemakalah dan belum mempunyai bahan. Sementara itu, untuk kegiatan publikasi hasil penelitian atau gagasan inovatif, alasan yang paling sering dikemukakan adalah keterbatasan waktu, belum percaya diri, dan belum 
punya bahan untuk ditulis. Selanjutnya untuk kegiatan publikasi buku teks pelajaran, buku pengayaan dan/atau pedoman guru adalah keterbatasan waktu, belum percaya diri, dan belum termotivasi. Dari beberapa alasan tersebut, belum percaya diri dan belum termotivasi merupakan salah satu faktor utama yang menjadikan kendala/hambatan mengapa alumni diklat masih belum melakukan kegiatan publikasi ilmiah setelah selesai mengikuti diklat. Hasil ini senada dengan hasil penelitian yang menyebutkan bahwa kemampuan dan motivasi memberikan pengaruh yang signifikan terhadap kinerja usaha tamatan diklat (Suwardie, 2009).

Berdasarkan alasan yang sering dikemukakan, maka ada beberapa pertimbangan atau saran yang diusulkankan agar setelah selesai mengikuti diklat $\mathrm{PKB}$ alumni dapat terfasilitasi lebih optimal dalam melakukan kegiatan PKB dimensi publikasi ilmiah. Pertama, perlu ada materi diklat yang secara khusus membahas bagaimana strategi mengikuti presentasi pada forum ilmiah sebagai pemrasaran/pemakalah. Kedua, perlu ada mata diklat PKB yang secara khusus dan detail membahas bagaimana melakukan publikasi ilmiah seperti yang diharapkan dalam Permenegpan dan RB Nomor 16 tahun 2009 dan Permendiknas Nomor 35 tahun 2010.

\section{Dimensi Karya Inovatif}

Dimensi karya inovatif terdiri atas kegiatan: menemukan teknologi tepat guna (karya sains/teknologi); menemukan/ menciptakan/mengembangkan karya seni; membuat/memodifikasi alat pelajaran/peraga; dan mengikuti kegiatan pengembangan penyusunan standar atau pedoman, soal, dan sejenisnya. Beberapa alasan yang dikemukakan mengapa belum melakukan kegiatan penemuan teknologi tepat guna (karya sains) adalah: belum punya kemampuan/ keterampilan komputer; terkendala dengan waktu; sudah tersedia beberapa media pembelajaran berbasis komputer; belum ada tuntutan; belum minat/termotivasi karena punya ide; membuatnya butuh waktu lama dan "ribet"; belum bisa komputer; belum tersedia fasilitas yang menunjang pembelajaran berbasis komputer; merasa sulit, be- lum merupakan tuntutan (keharusan). Sementara itu, beberapa alasan yang dikemukakan mengapa belum melakukan kegiatan penemuan/penciptaan karya seni adalah: belum punya ide/belum tahu seperti apa karya seni terkait pelajaran Matematika; merasa tidak punya jiwa seni; merasa bukan bidangnya; merasa tidak punya bekal pengetahuan/keterampilan seni; belum terpikirkan; keterbatasan waktu; dan tidak ada permintaan sehingga tidak membuat (meskipun punya bakat seni). Selanjutnya, beberapa alasan yang dikemukakan mengapa belum melakukan kegiatan membuat/memodifikasi alat pelajaran/alat peraga adalah: belum punya ide; belum tahu/jelas bentuknya seperti apa; keterbatasan waktu; belum termotivasi; belum ada tuntutan; merasa tidak kreatif; dapat membeli menggunakan dana sekolah, dan merasa tidak perlu karena jarang menggunakan alat peraga. Sementara itu, beberapa alasan yang dikemukakan mengapa belum melakukan kegiatan pengembangan penyusunan standar atau pedoman, soal, dan sejenisnya adalah: belum ada tawaran untuk mengikuti kegiatan penyusunan soal/standar/pedoman guru; diganti guru lain (gantian); dan sudah tidak menjadi guru matematika lagi.

Berdasarkan beberapa alasan yang dikemukakan tersebut, yang paling sering disampaikan mengapa belum melakukan kegiatan penemuan teknologi tepat guna (karya sains) adalah belum punya keterampilan komputer, keterbatasan waktu, dan belum termotivasi/berminat. Sementara itu, untuk kegiatan penemuan/penciptaan karya seni, alasan yang paling sering dikemukakan adalah belum punya ide/belum tahu seperti apa karya seni terkait pelajaran Matematika dan merasa tidak punya jiwa seni. Selanjutnya, untuk kegiatan melakukan pembuatan/pemodifikasian alat pelajaran/alat peraga adalah: belum punya ide; keterbatasan waktu, dan belum termotivasi. Sementara itu untuk kegiatan pengembangan penyusunan standar atau pedoman, soal, dan sejenisnya yang paling sering dikemukakan adalah belum ada tawaran untuk mengikuti kegiatan penyusunan soal/standar/pedoman guru. 
Berdasarkan alasan yang sering dikemukakan, maka ada beberapa pertimbangan atau saran yang diusulkan agar setelah selesai mengikuti diklat PKB alumni dapat terfasilitasi lebih optimal dalam melakukan kegiatan PKB dimensi karya inovatif. Pertama, terkait dengan struktur program diklat PKB: materi komputer perlu diberikan dengan menitikberatkan agar peserta diklat dapat mengetahui dan menguasai keterampilan komputer yang dibutuhkan untuk menunjang pembuatan/penemuan karya sains dalam bentuk media pembelajaran atau bahan ajar interaktif berbasis komputer; materi inovasi pembelajaran lebih dititikberatkan agar peserta diklat terfasilitasi dalam memunculkan ide-ide inovatif dalam pembelajaran, dan perlu adanya materi diklat yang secara khusus membahas karya seni dalam matematika. Kedua, perlu ada diklat PKB yang secara khusus memfokuskan pada produk karya inovatif. Sementara ini, berdasarkan isi dari struktur program diklat PKB tahun 2013 maupun tahun 2014, kedua diklat PKB tersebut lebih berorientasi agar peserta diklat mampu membuat karya tulis ilmiah.

Beberapa faktor yang menjadi kendala dalam melakukan kegiatan PKB pada dimensi pengembangan diri, publikasi ilmiah, maupun karya inovatif yang dikemukakan alumni di atas dapat dikelompokkan menjadi dua, yaitu kendala yang berasal dari faktor eksternal dan yang berasal dari faktor internal alumni. Kendala yang berasal dari faktor internal alumni lebih dikarenakan alasan yang bersumber dari dalam diri alumni sendiri seperti masih belum percaya diri, tidak mempunyai bahan, belum termotivasi, belum tertarik, belum merasa membutuhkan, dan belum punya keterampilan. Sementara itu, kendala yang berasal dari faktor eksternal alumni lebih dikarenakan alasan yang disebabkan dari luar alumni seperti tidak adanya tawaran atau kesempatan untuk mengikuti kegiatan, kebanyakan beban kerja, dan belum adanya tuntutan.

Beberapa faktor kendala yang telah dikemukakan di atas dapat dimungkinkan muncul karena belum adanya sinergi dari berbagai pihak yang turut berperan dalam suatu sistem diklat. Keberhasilan suatu program diklat pada tahap pascadiklat sangat dipengaruhi bagaimana peran atau keterlibatan dari masing-masing unsur seperti sekolah, dinas pendidikan, dan juga PPPPTK Matematika sebagai lembaga diklat. Ada tidaknya dukungan sekolah atau dinas pendidikan terhadap alumni diklat akan berpengaruh terhadap sikap atau perilaku alumni dalam usahanya menerapkan apa yang telah dipelajarinya selama diklat. Selain itu, ada tidaknya fasilitasi layanan pasca diklat terhadap alumni dari lembaga diklat PPPPTK Matematika juga ikut berpengaruh. Hal ini sesuai dengan pendapat Lynton \& Pareek (1978, p. 22) bahwa adanya perbaikan atau perubahan perilaku yang lebih efektif dalam pekerjaannya setelah selesai mengikuti diklat dipengaruhi oleh ada tidaknya dukungan organisasi saat alumni diklat kembali ke tempat kerja. Jika kolega dan atasannya menyetujui terhadap perilaku barunya, maka alumni akan cenderung untuk terus bersikap lebih efektif.

Perubahan perilaku alumni dalam melakukan kegiatan PKB setelah selesai mengikuti diklat tentunya juga tidak terlepas dari bagaimana pelaksanaan manajemen sekolah yang dilakukan oleh kepala sekolah alumni. Beberapa kendala alumni seperti: belum adanya tawaran/kesempatan untuk mengikuti kegiatan, kebanyakan beban kerja/jam mengajar, belum adanya tuntutan, belum termotivasi, dan belum mempunyai ide dimungkinkan karena belum berfungsinya kepala sekolah sebagai manajer, motivator, maupun inovator dengan optimal. Sikap maupun tanggapan kepala sekolah terhadap alumni diklat sekembalinya di sekolah akan ikut berpengaruh terhadap ada tidaknya perubahan perilaku alumni sebagai akibat dari hasil mengikuti diklat. Ini artinya, perilaku alumni setelah selesai mengikuti diklat juga akan dipengaruhi oleh bagaimana pelaksanaan manejemen sekolah di tempat alumni itu sendiri.

\section{Simpulan dan Saran}

Berdasarkan temuan data dan hasil analisis diperoleh simpulan bahwa Diklat 
PKB Guru Matematika yang diselenggarakan di PPPPTK Matematika tahun 2013 dan 2014 belum berdampak banyak terhadap perubahan perilaku alumni dalam melakukan kegiatan PKB menurut Permenpan dan RB nomor 16 Tahun 2009 dan Permendiknas nomor 35 tahun 2010 serta bentuk kegiatan PKB masih bervariasi mengingat beberapa hal sebagai berikut.

Pertama, bentuk kegiatan PKB yang dilakukan alumni setelah selesai mengikuti diklat masih bervariasi, yaitu: (a) sangat banyak alumni yang melakukan kegiatan PKB pada dimensi pengembangan diri yaitu dengan mengikuti kegiatan diklat fungsional dan mengikuti kegiatan kolektif guru; (b) sedikit alumni yang melakukan kegiatan PKB pada dimensi publikasi ilmiah yaitu presentasi pada forum ilmiah, publikasi ilmiah hasil penelitian atau gagasan inovatif, dan publikasi buku teks pelajaran, buku pengayaan dan/atau pedoman guru; (c) sangat sedikit alumni yang melakukan kegiatan PKB pada dimensi karya inovatif yaitu menemukan karya sains, menemukan/menciptakan karya seni, membuat/memodifikasi alat pelajaran/peraga, dan mengikuti penyusunan standar, pedoman, soal dan sejenisnya.

Kedua, beberapa faktor yang menjadi kendala belum dilakukannya kegiatan PKB setelah selesai mengikuti diklat pada dimensi pengembangan diri adalah: tidak adanya tawaran, keterbatasan waktu, belum pernah ada informasi maupun belum mengetahui seperti apa kegiatan kolokium dan diskusi panel. Sementara itu, pada dimensi publikasi ilmiah alasan yang paling sering dikemukakan adalah: tidak adanya tawaran untuk menjadi pemrasaran/pemakalah, belum mempunyai bahan, keterbatasan waktu, belum percaya diri, dan belum termotivasi. Selanjutnya, pada dimensi karya inovatif, alasan yang paling sering dikemukakan adalah: belum punya keterampilan komputer, keterbatasan waktu, dan belum termotivasi/ berminat, belum punya ide, belum tahu seperti apa karya seni terkait pelajaran matematika, dan merasa tidak punya jiwa seni.

Saran yang diberikan penelitian ini untuk lembaga diklat adalah: (1) dalam pe- milihan peserta diklat sebaiknya perlu mempertimbangkan kebutuhan/motivasi peserta diklat yang sebenarnya; (2) perlu memfasilitasi adanya kegiatan selain bentuk diklat dan seminar seperti kolokium maupun diskusi panel sehingga memungkinkan guru uintuk mengikutinya; (3) perlu adanya diklat atau mata diklat yang secara khusus memfokuskan pada produk karya inovatif; (4) perlu adanya media layanan pasca diklat melalui web PPPPTK Matematika.

Selanjutnya, saran untuk stakeholder (sekolah/dinas pendidikan/pemerintah pusat) yaitu: (1) perlu memfasilitasi adanya kegiatan pertemuan ilmiah selain seminar, seperti kolokium maupun diskusi panel sehingga memungkinkan guru untuk mengikutinya; dan (2) perlu memperbanyak adanya wadah publikasi ilmiah yang secara khusus diperuntukkan bagi karya-karya guru seperti jurnal atau buletin, baik ditingkat propinsi maupun kabupaten/kota/sekolah.

\section{Daftar Pustaka}

Abdillah, W., \& Jogiyanto. (2015). Partial least square (PLS): Alternatif structural equation modeling (SEM) dalam penelitian bisnis. Yogyakarta: Andi.

Azwar, S. (2012). Reliabiltas dan validitas (4th ed.). Yogyakarta: Pustaka Pelajar.

Badan Standar Nasional Pendidikan. (2015). Prosedur operasional standar penyelenggaraan ujian nasional tabun pelajaran 2015/2016. Jakarta: Badan Standar Nasional Pendidikan.

Goodall, J., Day, C., Muijs, D., \& Harris, A. (2005). Evaluating the impact of ontinuing Professional Development (CPD). Research Report No. 659. Retrieved from http://webarchive.nationalarchives.go v.uk/20130402123207/https://www.e ducation.gov.uk/publications/eOrderi ngDownload/RR659.pdf

Hair, J. F., Hult, G. T. M., Ringle, C., \& Sarstedt, M. (2014). A primer on partial least squares structural equation modeling (PLS_SEM). Los Angeles: SAGE. 
Kementerian Negara Pendayagunaan Aparatur Negara dan Reformasi Birokrasi. Peraturan Menteri Negara Pendayagunaan Aparatur Negara dan Reformasi Birokrasi Nomor 16 Tahun 2009 tentang Jabatan Fungsional Guru dan Angka Kreditnya (2009).

Kementerian Pendidikan Nasional Republik Indonesia. (2010). Buku 4: pedoman kegiatan PKB. Jakarta: Kementerian Pendidikan Nasional.

Kirkpatrick, D. L., \& Kirkpatrick, J. D. (2006). Evaluating training programs: the four levels (3rd ed.). San Francisco: Berrett-Koehler Publishers.

Lynton, R. P., \& Pareek, U. (1978). Training for development. Connecticut: Kumarian Press.

Napitupulu, E. L. (2015). Mutu guru belum menggembirakan. Retrieved March 20, 2015, from

http://print.kompas.com/baca/2015/ 07/07/Mutu-Guru-Belum-

Menggembirakan
Pusat Pengembangan dan Pemberdayaan Pendidik dan Tenaga Kependidikan Matematika. (2013). Buku panduan diklat in-on-in pengembangan keprofesian berkelanjutan (PKB) tanggal 18 sampai dengan 27 September 2013 di PPPPTK Matematika. Yogyakarta: PPPPTK Matematika.

Sarwono, J., \& Narimawati, U. (2015). Membuat skripsi, tesis, dan disertasi: Partial least square SEM (PLS-SEM). Yogyakarta: Andi.

Silberman, M. (2006). Active training: $A$ bandbook of techniques, designs, case examples, and tips (3rd ed.). San Francisco: Pfeirffer.

Suwardie, S. (2009). Model evaluasi kinerja tamatan pelatihan kewirausahaan Balai Diklat Pertanian DIY. Jurnal Penelitian Dan Evaluasi Pendidikan, 13(2). Retrieved from https://journal.uny.ac.id/index.php/jp ep/article/view/1407 